\title{
THE CONSTITUTIONAL ROLE OF THE JUDICIARY IN CASES OF SEXUAL GBV: AN ANALYSIS OF TSHABALALA $v$ S; NTULI $v S$ 2020 (5) SA 1 (CC)
}

\author{
Glancina Mokone \\ LLB LLM (cum laude) \\ Lecturer, Nelson Mandela University
}

\section{SUMMARY}

The Constitution of the Republic of South Africa is the supreme law, and it imposes obligations on all arms of the State, including the judiciary. In performing their functions and exercising their powers, all three arms of the State are obliged to fulfil the obligations imposed by the Constitution. In particular, all three arms of the State are bound by the provisions of the Bill of Rights. The Bill of Rights, provided for in the Constitution, is a cornerstone of democracy in the country. The Bill of Rights provides for fundamental human rights, which must be respected, protected, promoted and fulfilled by the State. Different legal systems recognised in the Republic also have to comply with the provisions of the Bill of Rights. In particular, section 39(2) of the Constitution provides that whenever legislation is interpreted and when the common law and customary law are being developed, the spirit, purport and objects of the Bill of Rights must be promoted. Therefore, even when a case before a court calls for the application of common law and all the principles applicable under common law, such application must comply with the provisions of the Constitution, including in cases of common-law rape. Gender-based violence has reached alarming rates in South Africa. The country is referred to as the "femicide nation" and the "rape capital of the world". With a Constitution that is supreme and entrenched, a Bill of Rights that provides for the protection and promotion of fundamental human rights, and obligations incurred in terms of international and African human-rights treaties, there are particular obligations placed on all three arms of the State, including the judiciary. All three arms of the State are obliged to comply with these provisions when addressing the scourge of gender-based violence in the country. This article conducts a critical analysis of the constitutional role of the judiciary in cases of sexua gender-based violence, with a focus on section 39(2) of the Constitution. The analysis is based primarily on the case of Tshabalala v S; Ntuli v S 2020 (5) SA 1 (CC).

\section{INTRODUCTION}

The Constitution of the Republic of South Africa, 1996 (the Constitution) is the supreme law of the Republic. ${ }^{1}$ This means that all laws have to comply with or be drafted within the parameters of constitutional provisions.

S 2 of the Constitution. 
Furthermore, all laws recognised in the Republic also have to comply with the obligations imposed by the Constitution as it is the supreme law. ${ }^{2}$ Lastly, all three arms of the State, including the judiciary, are obliged to fulfil the obligations imposed by the Constitution. ${ }^{3}$

The Bill of Rights makes provision for the protection and promotion of fundamental human rights, which are justiciable within South Africa's constitutional democracy. ${ }^{4}$ Section $8(1)$ of the Constitution places a particular obligation on all three arms of the State by stating the following:

"The Bill of Rights applies to all law, and binds the legislature, the executive, the judiciary and all organs of state."

This section means that whenever the three arms of the State perform their functions or exercise their powers, they are bound by the provisions of the Bill of Rights. Furthermore, reference to all law, as stated in this section, includes other laws recognised in the Republic - for example, common law and customary law, which are also subject to the provisions of the Bill of Rights. ${ }^{5}$ This is in line with section 7(1) of the Constitution, which provides that the Bill of Rights is a cornerstone of democracy in South Africa, and affirms the democratic values of human dignity, equality and freedom.

Section 39(1) of the Constitution provides that whenever a court interprets the Bill of Rights, these democratic values must be promoted. There is, therefore, a further obligation on the courts to give effect to these values whenever they interpret the Bill of Rights. Even though values are not justiciable, they do provide an important framework within which the rights in the Constitution are to be interpreted and given effect to; more particularly, they provide guidance to the courts on how rights are to be interpreted and ultimately given effect to.

The courts are also obliged to consider international law when interpreting the Bill of Rights. ${ }^{6}$ There are various United Nations (UN) and African human-rights instruments that provide the international and regional standard for the protection and promotion of rights in general, and women's rights in particular. For example, the UN Convention on the Elimination of all forms of Discrimination Against Women (CEDAW) and the African Charter on Human and People's Rights (ACHPR) provide the standard for the

2 S 2 of the Constitution; customary law and common law are recognised in South Africa as provided for in s 39(2) and (3) of the Constitution.

$3 \quad S 7(2)$ of the Constitution provides that the State must respect, protect, promote and fulfil the rights in the Bill of Rights; s 8(1) of the Constitution further provides that the Bill of Rights applies to all law, binds the legislature, the executive, the judiciary and all organs of state.

4 The Bill of Rights is provided for in Chapter 2 of the Constitution; the Bill of Rights provides for the following rights, among others: the rights to equality, human dignity, and freedom and security of the person. These are provided for in sections 9,10 and 12 respectively.

5 Various sections of the Constitution refer to common law - for example, ss 8(3)(a), 39(2), and 39(3). The Constitution also makes mention of customary law in ss 39(2) and (3), and 211(1).

6 Being a State Party to various treaties (for example the United Nations Convention on the Elimination of all forms of Discrimination Against Women (CEDAW), 1979 and the Protocol to the African Charter on Human and People's Rights on the Rights of Women in Africa (Maputo Protocol)), South Africa is obliged to fulfil the obligations it has incurred in terms of these treaties. See s $39(1)(b)$ of the Constitution; Tshabalala $v$ S; Ntuli $v$ S supra par 96. 
protection and promotion of the right to equality of all women in a similar manner to that of section 9 of the Constitution. ${ }^{7}$

Of particular significance to this article is section 39(2) of the Constitution, which obliges the courts to promote the spirit, purport and objects of the Bill of Rights when interpreting any legislation and when developing the common law or customary law. Where the common law deviates from or fails to comply with the provisions of the Constitution, it needs to be developed in a manner that will promote the spirit, purport and objects of the Bill of Rights.

Section 165(2) of the Constitution further states that the courts are independent and are subject only to the Constitution and the law. ${ }^{8}$ This would in effect also mean that the courts are subject to the common law where a matter requires or calls for the application of the common law. However, even when a matter does in fact call for the application of the common law, such application remains subject to particular constitutional provisions as stated in sections 2, 7(1), 8(1) and 39(1) and (2) of the Constitution. Therefore, even when a crime, such as common-law rape, is committed and such a matter must be considered according to the provisions of common law, the constitutional obligation placed on the courts to consider and determine the matter within constitutional parameters and provisions remains intact by virtue of sections $8(1), 39(1)(a)$ and (b), and section 39(2) of the Constitution. ${ }^{9}$

In essence, the courts are charged with the protection and promotion of the Constitution, and in particular the protection and promotion of the Bill of Rights, whenever they perform their functions or exercise their powers, even in instances where the common law finds application. Section 167(3)(a) states that the Constitutional Court is the highest court of the Republic; thus, this section places a particular and greater obligation on this court to fulfil the obligations imposed by the Constitution, and the Bill of Rights in particular, as it will set the standard and precedent for all other courts of the Republic. ${ }^{10}$

In recent years and more especially during the national lockdown period, gender-based violence has been on the rise in South Africa. ${ }^{11}$ Incidents of gender-based violence have also become more violent. ${ }^{12}$ Central to this

7 It is important to mention that while these international and African human-rights instruments set the international and regional standard, the Constitutition does go further in its provisions when providing for the promotion and protection of the right to equality as stated in $\mathrm{s} 9$ of the Constitution.

8 This is again in line with s 2 (supremacy clause) of the Constitution.

9 This is because common-law rape infringes rights that are recognised and protected in the Bill of Rights, for e.g., the rights to human dignity and freedom and security of the person, to name a few. These rights are provided for in ss 10 and 12 of the Constitution respectively.

10 Ss 168,169 , and 170 of the Constitution make reference to other courts that are recognised in the Republic. These are the Supreme Court of Appeal, the High Courts, and other courts, for e.g., the Labour Court and small claims courts, to name a few. Due to the Constitutional Court being the apex court in the country and the doctrine of judicial precedent, as founded on judicial hiearchy, there is a particular and greater obligation on the Constitutional Court to promote and protect the spirit, purport and objects of the Bill of Rights.

11 South Africa declared a national lockdown on 23 March 2020 in terms of the National Disaster Management Act due to the global Covid-19 pandemic.

12 To date, incidents of gender-based violence have become more violent where, for example, women's bodies are often discovered in horrifying conditions. The most recent incident is 
article is section 39(2) of the Constitution, and in particular, the application of the common-law doctrine of common purpose to matters of common-law rape. Against this backdrop, the article analyses the case of Tshabalala $v S$; Ntuli $v S,{ }^{13}$ in which the Constitutional Court had to develop the common law within the provisions and parameters of section 39(2) of the Constitution by determining whether the doctrine of common purpose is applicable in matters of common-law rape.

Prior to the decision of the court in this case, there was uncertainty in the law with regard to the application of the doctrine of common purpose to matters of common-law rape. This uncertainty resulted in conflicting application of the doctrine in matters of common-law rape.

As previously stated, all three arms of the State, which include the judiciary, have obligations to fulfil (in terms of the Constitution and international and African human-rights treaties) to protect and promote human rights, especially those of women. This article considers the role of the judiciary, through the determination, development and application of the law, in the fight against gender-based violence, its constitutional, international, and regional human-rights obligations in terms of ratified treaties and other legal instruments with regard to the protection and promotion of human rights, particularly for women.

The case of Tshabalala $v S$; Ntuli $v S$ is introduced in the next section.

\section{2}

\section{INTRODUCTION TO THE CASE: TSHABALALA $v$ S; NTULI v $S$}

Mathopo AJ, in his opening remarks, stated:

"Rape is a very serious offence, constituting as it does a humiliating, degrading and brutal invasion of the privacy, the dignity and the person of the victim. The rights to dignity, to privacy, and the integrity of every person are basic to the ethos of the Constitution and to any defensible civilisation. Women in this country are entitled to the protection of these rights."14

In the case of Tshabalala $v S$; Ntuli $v S$, the Constitutional Court had to determine whether or not the common-law doctrine of common purpose is applicable in matters of common-law rape. The doctrine of common purpose entails the following: if two or more people, having a common purpose to commit a crime, act together in order to achieve that purpose, the conduct of each of them in the execution of that purpose is imputed to the other. ${ }^{15}$ Prior to the Constitutional Court's decision in this case, there was no clarity and certainty in our law as to the application of the doctrine in matters of common-law rape; the doctrine was applied in some cases and excluded in

that of Tshegofatso Pule whose body was discovered hanging from a tree while she was 8 months pregnant (News 24 "Man accused of Tshegofatso Pule's murder confesses to previous failed attempt" https://www.news24.com/news24/southafrica/news/ man-accusedof-tshegofatso-pules-murder-confesses-to-previous-failed-attempt-report-20200618 (accessed 2020-09-08)).

13 Supra.

14 Tshabalala v S; Ntuli v S supra opening remarks.

15 Snyman Criminal law 6ed (2014) 256. 
others. ${ }^{16}$ Rape has been on a steady rise over the last three years. In particular, sexual offences committed against women have been on a steady rise. ${ }^{17}$

\section{Facts of the case}

On 20 September 1998, a group of men went on the rampage in the township of Tembisa in Gauteng. ${ }^{18}$ During this time, the men, including Tshabalala and Ntuli, forced their way into numerous homes which were located on nine separate plots in a community where marginalised and vulnerable people, mostly women and children, lived. Once forceful entry was gained, the men ransacked, looted and, in one case, stabbed one of the occupants. ${ }^{19}$ On approaching some of the houses, they threw rocks and stones on the roofs, sowing confusion by masquerading as police. When their entry was refused, they broke down doors and assaulted the occupants they found inside. ${ }^{20}$ Some of the males in the homes were also attacked and they were made to lie on the ground with blankets covering their heads. The violent acts included the rape of eight female occupants, some of whom were repeatedly raped, by several members of this group. ${ }^{21}$ The youngest victim of these crimes was 14 years old and another victim was a woman who was visibly pregnant; this did not deter the group from committing these crimes. ${ }^{22}$ It is important to note that while some of the men raped the female occupants, other members of the group were standing guard outside the homes in which these violent crimes were taking place. Essentially, they were posted to act as lookouts or guards for the other members of the group.

On 13 August 1999, this matter was brought before the High Court on a charge of common-law rape mainly based on the common-purpose doctrine.

\section{Proceedings in the High Court}

Mr Tshabalala and his other co-accused ${ }^{23}$ were found guilty of eight counts of rape, seven of which were imposed on the basis of the application of the

\footnotetext{
16 There are a number of court cases that reflect the uncertainty in our law around the application of the common-purpose doctrine to matters of common-law rape. A discussion of these cases will follow in a later section of this note.

17 Crime Stats South Africa Stats Simplified: https://www.crimestatssa.com/national.php (accessed 2020-02-14); South African Police Service "Crime Situation in Republic of South Africa Twelve (12) Months (April to March 2018_19)" https://www.saps.gov.za/services/april_to_march2018_19_presentation.pdf (accessed 2020-02-14).

18 Tshabalala $v$ S; Ntuli $v$ S supra par 5.

19 Ibid.

Tshabalala $v$ S; Ntuli $v$ S supra par 6.

1 Ibid.

Ibid.

23 For the purposes of this note, reference will only be made to Mr Tshabalala and Mr Ntuli who were the applicants in this case. As and when it is necessary, reference will be made to the other co-accused who were part of the group of men referred to above as the "other coaccused" or will be referred to by name specifically when necessary.
} 
doctrine of common purpose. ${ }^{24}$ Both $\mathrm{Mr}$ Tshabalala and Mr Ntuli were postively identified at different scenes where the crimes took place.

Mr Tshabalala was identified in household eight where an attempted rape took place and was further identified at an outside toilet. ${ }^{25} \mathrm{Mr}$ Ntuli was identified at two different locations where the crimes took place. In one of the households where Mr Ntuli was seen, the occupants were assaulted and one of the female occupants was raped by more than two men. ${ }^{26}$

The applicants contended that the common-law crime of rape is not an offence for which an individual can be convicted through the application of the doctrine of common purpose. This contention, however, was rejected by the High Court. ${ }^{27}$ In deciding if the doctrine should indeed be applicable to the common-law crime of rape, the High Court evaluated the evidence and arrived at the conclusion that the group acted as a "cohesive whole". ${ }^{28}$

In support of this conclusion, the court held that the fact that blankets were placed over some of the occupants while the women and children were being raped, and that some members of the group were posted outside as lookouts, could only point to one conclusion, namely that the attacks were not spontaneous, but were planned. Therefore, a common purpose was formed before the attacks began and before the rapes were executed in order to further the common purpose. ${ }^{29}$

The reasoning of the court was based on the following: (a) both applicants were at the scene of the crimes with the group; (b) both applicants were identified by some of the witnesses at the scene and also at the identification parade; (c) both applicants must have known, or been aware of, the group's modus operandi to commit the crimes; and (d) both applicants did not disassociate themselves from the actions of the group. ${ }^{30}$ Both accused were convicted and sentenced to effective life sentences.

They sought leave to appeal from the High Court, which was refused. Mr Tshabalala later also petitioned the Supreme Court of Appeal for leave to appeal, which was also refused. However, what incited both Mr Tshabalala and Mr Ntuli to appeal to the Constitutional Court was the decision of the Full Court with regard to a Mr Phetoe, who was a co-accused in the matter.

Mr Phetoe was granted leave to appeal both his conviction and sentence on 28 November 2012 to a Full Court of the High Court. The Full Court reasoned that due to the State's failure to prove beyond reasonable doubt that each member of the group did indeed rape the eight complainants, the convictions of rape based on the application of the doctrine of common purpose had to be set aside. ${ }^{31}$ The Full Court held further that the doctrine cannot be applied to crimes that can only be committed through the use of

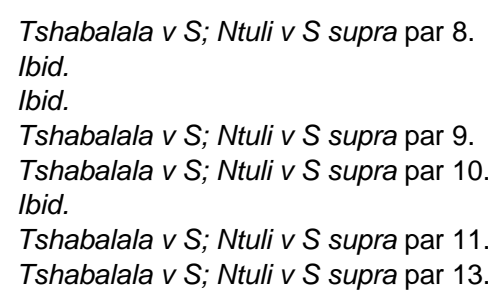


one's own body, or part thereof, and not through the instrumentality of another person. ${ }^{32}$

Therefore, the Full Court overturned Mr Phetoe's common-law rape conviction, replacing it with one of being an accomplice, and sentenced him to one term of life imprisonment instead. ${ }^{33}$ The Full Court arrived at this decision after it determined that Mr Phetoe did not dissociate himself from the group, including the rapes.

However, Mr Phetoe was dissatisfied with this finding and subsequently applied for, and was granted, special leave to appeal to the Supreme Court of Appeal.

In the section that follows is a discussion of the proceedings in the Supreme Court of Appeal with regard to Mr Phetoe's special leave to appeal.

\section{Proceedings in the Supreme Court of Appeal}

The Supreme Court of Appeal (SCA) held differently; it did not agree with the decision of the Full Court. The SCA held instead that to convict the appellant as an accomplice to the crime on the basis of his mere presence at the scene "would subvert the principles of participation and liability as an accomplice in our criminal law". ${ }^{34}$ The SCA stated that there was no evidence to prove that Mr Phetoe was indeed present at the scene where the rapes, assaults, housebreakings, and robberies took place, other than at household three, and thus concluded that no common purpose with the other members of the group was established. ${ }^{35}$ Further to this, the court stated that Mr Phetoe did not meet the requirements of an accomplice and to hold him accountable as such would amount to a subversion of the principles of participation and liability as an accomplice in our criminal law. ${ }^{36}$

It was on this basis that the SCA set aside the convictions and sentences of all counts of common-law rape but confirmed Mr Phetoe's conviction and sentence in respect of the robbery with aggravating circumstances. ${ }^{37}$

Ibid.

33 In the minority judgment at par 9 of the case as it was heard in the Supreme Court of Appeal, it is recorded that Dama AJ held differently. Dama AJ held that there was no evidence presented by the State to prove that Mr Phetoe assisted the rest of the accused in any form at the time the rapes were committed, except for the fact that he was present at the scene. Dama AJ was of the opinion that Mr Phetoe should not be held liable.

$34 \quad$ Tshabalala $v$ S; Ntuli $v$ S supra par 15.

35 Tshabalala $v$ S; Ntuli $v$ S supra par 15; Phetoe $v$ S 2018 (1) SCA par 10, 15, 16, 17, 20 and 21.

36 Phetoe $v S$ supra par 15; in par 13 of the case, the court referred to the definition of an accomplice in Snyman Criminal Law 266 in the following manner: "a person is guilty of a crime as an accomplice if, although he does not satisfy all the requirements for liability contained in the definition of the crime and although the conduct required for a conviction is not imputed to him by virtue of the principles relating to common purpose, he unlawfully and intentionally engages in conduct whereby he furthers the commission of a crime by somebody else."

37 Phetoe v S supra par 20; the SCA did not engage, in this matter as it was on appeal, on the application of the doctrine of common purpose itself. It only applied itself to the appeal of the conviction and sentence of being an accomplice to the crimes of common-law rape. 
The SCA overturned the findings of the High Court, which were based on the application of the doctrine of common purpose, and those of the Full Court that Mr Phetoe was an accomplice to the rapes. ${ }^{38}$ Therefore, the SCA set aside the convictions and sentences relating to all the convictions on common-law rape. The decision of the SCA conformed to the minority judgment in the High Court. ${ }^{39}$

As a result of Mr Phetoe's successful appeal and decision by the SCA, both Mr Tshabalala and Mr Ntuli applied to the Constitutional Court in December 2018 for leave to appeal their convictions and sentences respectively.

\section{Proceedings in the Constitutional Court}

The Constitutional Court was charged with answering two main questions, namely: (a) whether an accused can be convicted of common-law rape based on the application of the doctrine of common purpose; and (b) whether the decision of the SCA in the case of Mr Phetoe was indeed correct, and if correct, whether there was anything to distinguish the convictions of Mr Tshabalala, which he put in dispute, from those from which his co-accused, Mr Phetoe, was absolved. ${ }^{40}$

\section{The uncertainty around the application of the common-purpose doctrine to common-law rape}

As previously stated, the Constitutional Court founded its jurisdiction in this case on the fact that there was uncertainty in our law with regard to the application of the doctrine of common purpose to common-law rape. What is key in the common-law doctrine, particularly in matters of rape, is the instrumentality principle. This principle requires that the person who is accused of rape be the one that actually penetrated the victim unlawfully through the use of his own genitalia. ${ }^{41}$ This would therefore mean that in matters of group rape, where common purpose may be established, but before an individual in the group can be convicted and sentenced for common-law rape, it must be proved beyond reasonable doubt that this particular individual did in fact penetrate the victim without consent through the use of his own genitalia. It was, therefore, important that the court make a determination as to the application of the doctrine in matters of commonlaw rape. Before the court could decide if the doctrine should indeed apply, it considered: the facts of previous cases in which the application of the doctrine of common purpose in matters of common-law rape was considered; how the law was applied in those cases; and, if there was anything in those previous cases that could possibly be used in the present case to assist the court in arriving at a conclusion.

Tshabalala $v$ S; Ntuli $v$ S supra par 16

Tshabalala $v$ S; Ntuli v $S$ supra par 13

Tshabalala $v$ S; Ntuli $v$ S supra par 18

Tshabalala $v$ S; Ntuli $v$ S supra par 2. 
What follows is a brief discussion of select previous cases referred to by the Constitutional Court in the present case.

In $S \vee$ Moses, ${ }^{42}$ the appellant was a member of a group charged with a number of crimes, which included common-law rape. The court had to determine whether or not the doctrine should be applicable to common-law rape. The minority in this case determined that the doctrine should be applicable, as the facts called for its application. ${ }^{43}$ Thus, the minority in this case did not consider the instrumentality principle to play a role or to be relevant in matters of common-law rape.

In Kholosa $v$ The State, ${ }^{44}$ the court had to decide an appeal that also included a charge of common-law rape. When deciding the issue of rape in this case, the court determined that the doctrine could not be applied to common-law rape. The court based its decision largely on the instrumentality principle. ${ }^{45}$

Lastly, in $S v$ Jaars, ${ }^{46}$ the court had to decide an appeal in which some of the rape convictions were based on the doctrine of common purpose. However, the court determined that the instrumentality principle is the determinative factor in matters of rape and therefore the convictions of the court a quo were set aside. ${ }^{47}$

These three cases illustrate the uncertainty that existed in our law insofar as the application of the doctrine of common purpose to common-law rape is concerned and the relevance of the instrumentality principle in common-law rape. It is this uncertainty that provided the need for the Constitutional Court to establish certainty and authority that could be used by other courts in similar cases.

\section{ANALYSIS}

In the present case of Tshabalala $v$ S; Ntuli $v$ S, the Constitutional Court noted that sexual violence committed against women is particularly prevalent and strips women of their rights to equality, human dignity and bodily integrity. Importantly, the court also acknowledged three aspects of genderbased violence: first, that the incidence of sexual violence in South Africa is high; secondly, that incidents of sexual violence in South Africa are gendered; and thirdly, that sexual gender-based violence infringes many of women's rights, including the right to equality. ${ }^{48}$ The crime of rape strips

42 (2010) JDR 0851 NCK; also referred to in par 23 of the facts of Tshabalala $v$ S; Ntuli $v$ S supra.

$43 \mathrm{Ibid}$; the court likened the defintion of rape to that of robbery and held that the distinction is artificial and more perceived than real.

442012 JOL 29419 ECG; also referred to in par 24 of the facts of Tshabalala $v$ S; Ntuli $v$ S supra.

45 Ibid.

462018 JDR 1026 GJ; also referred to in par 25 of the facts of Tshabalala v S; Ntuli v S supra.

47 lbid.

48 Tshabalala v S; Ntuli v S supra par 1. 
women of rights that are protected in the Constitution, national legislation and international and regional treaties. ${ }^{49}$

Rape, by its very nature, has criminal, physical, emotional and social elements attached to it. Rape has very little to do with non-consensual penetration; the very nature of rape far exceeds its legal and social definitions and consequences. ${ }^{50}$ Within its social context, rape has to do with the assertion of power that expresses itself violently in a sexual, degrading, and intrusive manner. The assertion of this power is often gendered as it is typically exerted by men at the expense of women. ${ }^{51}$ Further to this, women who have experienced rape as victims and survivors do not experience rape as a sexual encounter but as a frightening, life-threatening attack and "as a moment of immense powerlessness and degradation". 52

Within its legal context, rape infringes the rights to equality, human dignity, freedom and security of the person, and privacy. Rape is a crime that is often committed against women and the perpetrators of this crime violently take what they have no permission to take; they enter into a personal space they have no permission to enter.

In the present case, the Constitutional Court noted, in particular, the scourge of rape against women in the country, more specifically incidents of group rape. ${ }^{53}$ The doctrine of common purpose is applicable in instances

49 Equality and human dignity are provided for, first, as values and, secondly as justiciable human rights within ss $1(a), 7(1), 9$ and 10 of the Constitution respectively; s 12 of the Constitution provides for the right to freedom and security of the person as violence constitutes a grave invasion of personal security; s 12(1)(c), in particular, provides for the right to be free from all forms of violence from either public or private sources; s 12(2) further provides for the right to bodily and psychological integrity, which includes the right to security in and control over a person's body; s 14 of the Constitution also provides for the right to privacy. For the purpose of this article, focus is placed on this right generally. When a person invades someone's person or body without their permission, there is a violation of this right. Rape by its very nature constitutes an invasion of the right to privacy as consent or permission to access another person's body is lacking. However, this is not to reduce incidents of sexual gender-based violence to a lack of mere consent. What is clear is that the rights to equality, human dignity, privacy, and bodily integrity are all linked in matters of sexual gender-based violence. With regard to national legislation, the Domestic Violence Act 116 of 1998 provides for the issuing of protection orders in cases where domestic violence has taken place; Criminal Law (Sexual Offences and Related Matters) Amendment Act 32 of 2007 provides for offences such as rape. The United Nations (UN) instruments that provide for the protection of the human rights of women are: the Universal Declaration of Human Rights (UDHR), 1948; the Convention on the Elimination of all forms of Discrimination Against Women (CEDAW), 1979; and the Sustainable Development Goals (SDGs), 2015, specifically goal 5 and goal 5.2. South Africa ratified the UDHR on 7 November 1945 and CEDAW on 15 December 1995. At a regional level, the following instruments provide for the protection and promotion of the human rights of women: the African Charter on Human and People's Rights (ACHPR), 1981; and the Protocol to the African Charter on Human and People's Rights on the Rights of Women in Africa (Maputo Protocol), 2003. South Africa ratified the ACHPR in 1996; in the concurring judgment, Victor AJ also referred to the influence of international law in the present case in par 93, 94, 95.

50 Statistics South Africa ("Quantitative Research Findings on Rape in South Africa" http://www.statssa.gov.za/publications/Rape/Rape.pdf (accessed 2020-05-06)) has recorded that rape has been defined in various ways, including legal, psychological, sociological and subjective definitions.

$51 \quad$ Tshabalala $v$ S; Ntuli $v$ S supra par 44.

52 Tshabalala $v$ S; Ntuli v S supra par 70.

53 Tshabalala $v$ S; Ntuli $v$ S supra par 31. 
where there is a group of people acting together with a common purpose and therefore carry and share the same legal liability. Of importance to common-law rape, as previously stated, is the instrumentality principle. This principle requires the perpetrator to actually penetrate the victim, without their consent, through the use of their own genitalia. However, the court determined the instrumentality principle to be irrelevant and inapplicable to the doctrine of common purpose with regard to common-law rape, and thereby rendered the instrumentality principle a non-requirement in matters of group rape. The irrelevance of this principle was considered within the social and legal environment of the country - for example, the obligations imposed on the courts according to section 39(2) of the Constitution.

National legislation has to be interpreted in a manner that promotes the spirit, purport and objects of the Bill of Rights. In addition, the common law itself has to be developed in the same manner. ${ }^{54}$ The court also considered the definition of rape as provided for in the Criminal Law (Sexual Offences and Related Matters) Amendment Act ${ }^{55}$ (SORMA). SORMA expands the definition of rape to no longer include instrumentality as a requirement for a rape conviction. ${ }^{56}$ The definition of rape now encapsulates more than just the insertion of male genital into female genitalia. ${ }^{57}$ SORMA defines rape in the following manner:

"Any person $(A)$ who unlawfully and intentionally commits an act of sexual penetration with a complainant $(B)$, without the consent of $B$, is guilty of the offence of rape." 58

The above definition of rape, read in conjunction with the definition of sexual penetration ${ }^{59}$ in SORMA, further expands the definition to include, for example, inanimate objects that are inserted into the genital organs or anus of a person without their consent. ${ }^{60}$ This also extends the application of the doctrine of common purpose with regard to common-law rape. ${ }^{61}$ Furthermore, section 55 of SORMA provides:

"Any person who: (a) attempts; (b) conspires with any other person; or (c) aids, abets, induces, incites, instigates, instructs, commands, counsels or procures another person, to commit a sexual offence in terms of this Act, is guilty of an offence and may be liable on conviction to the punishment to which a person convicted of actually committing that offence would be liable."

$54 \quad$ Tshabalala v S; Ntuli v S supra par 98; s 39(2) of the Constitution oblies the courts to promote the spirit, purport and objects of the Bill of Rights when interpreting any legislation and when developing the common law.

5532 of 2007.

56 In the concurring judgment by Victor AJ in par 80 , it is stated that the instrumentality principle has no place in South Africa's modern society; see the Preamble to SORMA and Tshabalala $v$ S; Ntuli $v$ S supra par 97.

57 As previously defined under common law.

58 S 3 of SORMA.

59 S 1 of SORMA.

60 The definition of sexual penetration in SORMA reads: 'sexual penetration' includes any act which causes penetration to any extent whatsoever by- (a) the genital organs of one person into or beyond the genital organs, anus, or mouth of another person; (b) any other part of the body of one person or, any object, including any part of the body of an animal, into or beyond the genital organs or anus of another person; or (c) the genital organs of an animal, into or beyond the mouth of another person.

$61 \quad$ Tshabalala $v$ S; Ntuli v S supra par 69 and 97. 
According to the above section, the conduct of a person that falls within the requirements of subsections (a) to (c) may be subject to the same punishment as that of the actual perpetrator on conviction. As a result, even though the conduct of the actual perpetrator may not necessarily be imputed to another, if any one of the requirements listed in section 55 is met, such a person may be liable to the same punishment as the perpetrator who in fact committed the act of unlawful sexual penetration. From a legislative perspective, and with regard to the facts of Tshabalala $v S$; Ntuli $v S$, this is a step in the right direction towards combating gender-based violence, especially with regard to incidents of group rape. In instances of group rape, where not all members of a group have personally and unlawfully penetrated the victim themselves, but might have aided in the rape of the victim, a member of such a group may be liable to the same punishment as the perpertartor who committed the act of unlawful sexual penetration.

The inclusion of this section in the present Act, and the decision of the Constitutional Court in the present case, are examples of how both arms of the State (the legislature, and the judiciary in particular) have sought to fulfil their constitutional obligations in terms of section 8(1) of the Constitution. The court's reference to international and regional treaty obligations also illustrates how the national executive has further enabled the court to determine the relevance of the instrumentality principle in our society. ${ }^{62}$

The definition of rape, as stated in SORMA, clearly excludes the commonlaw requirement of instrumentality, which required the accused personally, through the use of his own genitalia, to penetrate a victim without the requisite consent. Furthermore, this definition of rape now develops the common law in line with the spirit, purport and objects of the Bill of Rights. SORMA, therefore, further elaborates and settles the legal parameters within which a person can be convicted of committing the crime of common-law rape.

This determination resulted in the extension and application of the doctrine of common purpose to common-law rape.63 Therefore, the development of the common law by the Constitutional Court according to constitutional provisions has played a significant role in this ground-breaking judgment; the uncertainty in our law was finally settled at the highest judicial level.

In essence, this determination resulted in two members of the group namely, Tshabalala and Ntuli, who were both positively identified at different scenes where the rapes were committed - being convicted of common-law rape albeit they did not penetrate the victim personally through the use of their genitalia. This determination by the Constitutional Court eradicated the uncertainty that hovered over the application of the doctrine of common purpose to common-law rape. The court also assumed an empathetic and sympathetic approach toward victims in reaching its decision; this is evident

62 S 231(1) of the Constitution provides that negotiating and signing of all international agreements is the responsibility of the national executive.

63 Tshabalala $v$ S; Ntuli $v$ S supra par 97. 
in the choice of words the court used throughout the case. ${ }^{64}$ Though the court assumed this perhaps unusual approach, its decision was still within constitutional parameters and international law obligations. ${ }^{65}$ In the concurring judgment, Victor AJ stated that the obligations imposed on the judiciary by the Constitution and international law provide the legal and logical basis to confirm the application of the doctrine of common purpose to the common-law crime of rape. ${ }^{66}$ This judgment focused on two main points - namely, feminist legal theory and the use of international law in pronouncing on the development of common law. ${ }^{67}$ Further to this, past rules that presented evidential obstacles to victims of sexual assault were also considered and it was within this context that the development of the common law and the instrumentality principle, as they relate to rules of evidence and procedure, were considered. ${ }^{68}$ South Africa has ratified multiple international instruments, and thereby incurred obligations that have to be fulfilled. ${ }^{69}$ These have been discussed previously - for example, the CEDAW and the Maputo Protocol.

It is also important to mention that the court used a stern and reprehensive tone and language as it detailed the facts of this case and when applying the law to the facts. This further illustrates the seriousness with which the court took its role in deciding this case.

Prior to the Constitutional Court reaching its decision in this case, there was no clarity and certainty in our law with regard to the application of the doctrine of common purpose to common-law rape and therefore, there was uncertainty as to when it should be applied. This uncertainty in our law had the further potential to create uncertainty in victims of rape with regard to the protection they would be afforded and entitled to in terms of the law, espcially when their cases are before the courts. Therefore, the findings by the Constitutional Court clarify first, the commitment of the judiciary to

64 The Constitutional Court used words, phrases or sentences such as at par 68, "Who knows what the black woman thinks of rape? Who has asked her? Who cares?", and at par 70, "for many victims and survivors of rape, they "do not experience rape as a sexual encounter but as a frightening, life-threatening attack" and "as a moment of immense powerlessness and degradation".

65 The court referred to the Bill of Rights and the international law obligations South Africa has incurred as a State Party to various international treaties (par 99).

66 Tshabalala $v$ S; Ntuli $v$ S supra par 99.

67 Tshabalala $v$ S; Ntuli $v$ S supra par 79. Feminist legal theory was raised in par 81, 85, 91 , and 92 of the case. This theory as argued in the present case focused on the dignity and privacy of women. Victor AJ also referenced other developments that have taken place in our legal system with regard to rape in par 80 - for e.g., the so-called marital rape exemption in which a husband could not be convicted for raping his wife; the medieval hueand-cry rule that required the victim to make a loud outcry immediately after being raped; and the cautionary rule, which was a warning to judicial officers that the evidence of complainants, such as witnesses in cases of sexual assault, could not be safely relied upon without corroboration. These have all been abolished. Par 82 of the present case also refers to past adherence to evidential obstacles such as the prompt complaint rule, multiple witness consistency, and the identification of the first witness to whom the rape was reported, all of which underpinned gender bias against victims of sexual assault.

68 Tshabalala $v$ S; Ntuli $v S$ supra par 83. Par 86 of the case indicates that accepting the doctrine of common purpose is a step towards the start of the end of sexism in rape trials.

69 Tshabalala $v$ S; Ntuli $v$ S supra par 93. The Preamble to SORMA also refers to international legal instruments in terms of which South Africa has incurred obligations toward combatting and ultimately eradicating gender-based violence. 
addressing the scourge of gender-based violence; secondly, it illustrates the commitment by the judiciary to fulfil its constitutional and international law obligations; and thirdly, the Constitutional Court has determined that the doctrine of common purpose is applicable in matters of common-law rape. ${ }^{70}$ This also illustrates the significant role of the law in addressing genderbased violence. ${ }^{71}$

When interpreting and giving effect to the rights in the Bill of Rights, the courts are mandated to promote the values that underlie an open and democratic society based on human dignity, equality and freedom. In deciding this case, the Constitutional Court referred to other rights that are protected and promoted in the Bill of Rights - for example, the rights to freedom and security of the person and privacy. This further illustrates how the rights in the Bill of Rights are interdependent.

\section{CONCLUSION}

Violence against women, more specifically violence that manifests itself sexually, has been on a steady increase. It is important to mention that, by their nature, women are not vulnerable and weak human beings; they are resilient, strong, intelligent, capable and nurturing beings; it is the exertion of male power that is often gendered and sexually violent that makes women vulnerable and marginalises them in society. Violence that is tailor-made to target and single out women does result in women occupying a weakened and vulnerable position in their own society. This is because gender-based violence infringes the most basic human rights of women. Thus far, it is clear that laws, policies, year-long awareness campaigns and every mechanism that has been established to combat and ultimately eradicate gender-based violence are proving to be ineffective and insufficient.

Furthermore, the circumstances in which this violence takes place seem to worsen with every act of violence. ${ }^{72}$ Insofar as the law is concerned with regard to the prevention, prohibition and elimination of gender-based violence, there is no lack, especially considering that South Africa makes appropriate provisions in the Constitution, which is supreme and entrenched; it has also ratified various international and regional treaties that seek to combat and eradicate gender-based violence. ${ }^{73}$

There are, in addition, various campaigns in place that seek to address and create awareness about gender-based violence, but even these have thus far proved to be ineffective. What is proving to be a particular challenge in combating and ultimately eradicating the scourge of rape are the values

70 See Tshabalala $v$ S; Ntuli $v$ S supra par 87 , where Victor AJ referred to a judgment in which Moseneke DCJ expanded on the doctrine of common purpose.

71 Tshabalala $v$ S; Ntuli $v$ S supra par 84. The criminal justice system imposes heavier sentences through the Criminal Law Amendment Act 105 of 1997 in respect of certain serious offences as provided in $\mathrm{s} 51$.

72 Tshabalala v S; Ntuli v S supra par 61.

73 Tshabalala v S; Ntuli v S supra par 96. S 231(1) of the Constitution states that negotiating and signing all international agreements is the responsibility of the national executive. To this end, South Africa has ratified various international agreements as previously mentioned. 
held by society about gender-based violence in general and gender-based sexual violence in particular. Therefore, the eradication of gender-based violence will need to be a committed social compact between society, ${ }^{74}$ the government and civil society organisations. ${ }^{75}$ Secondly, awareness campaigns also have to be tailor-made for specific communities. This is necessary in order to create a real understanding of what kind of behaviour causes or results in gender-based violence; why the protection and promotion of women's human rights is important; why it is important to identify and change harmful attitudes that have the potential to further perpetuate incidents of gender-based violence; and lastly, why it is important to reaffirm women's place in society.

The role and significance of societal values and attitudes were also noted by the Constitutional Court in this case. ${ }^{76}$ Therefore, the Constitutional Court, through the determination, development and application of the common law is to be commended for acknowledging the role of the judiciary, first, in the protection and promotion of constitutional rights and values; secondly, in fulfilling its constitutional and international law obligations; and thirdly, in reaffirming the place of women in society by seeking to combat genderbased violence through the development of the common law in terms of the provisions of section 39(2) of the Constitution.

Every victory, especially at such a level, is a step in the right direction towards the ultimate elimination of gender-based violence and the realisation of constitutional rights for all, including especially women. This case illustrates how the Constitutional Court fulfilled its mandate; gave effect to its obligations in terms of the Constitution; also further reaffirmed the significance of the Bill of Rights within South Africa's constitutional democracy; and lastly, set a precedent for all other courts in the country. The court undertook a constitutional and human-rights based approach to criminal law.

$74 \quad$ Tshabalala v S; Ntuli v S supra par 84.

75 Tshabalala v S; Ntuli v S supra par 85.

76 Tshabalala v S; Ntuli v S supra par 92. 